\title{
Enhancing Socio-Economic Rights in the
} Mashonaland Central Province of Zimbabwe through Fiscal Decentralization: Progress and Challenges

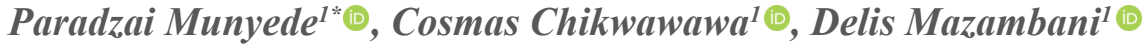

College of Business, Peace, Leadership and Governance, Africa University, Mutare, Zimbabwe

* Corresponding Author (munyedep@africau.edu)

Received: 22 August, 2021

Revised: 15 October, 2021

Accepted: 19 November, 2021

Published: 25 December, 2021

How to cite this paper:

Munyede, P., Chikwawawa, C., Mazambani, D. (2021). Enhancing socio-economic rights in the Mashonaland central province of Zimbabwe. Quest Journal of Management and Social Sciences, 3(2), pp. 277-290.

Copyright (C) 2021 by authors and Quest Journal of Management and Social Sciences.

This work is licensed under a Creative Commons Attribution-Non Commercial-No Derivatives 4.0 International License.

https://creativecommons.org/ licenses/by-nc-nd/4.0/

\section{Abstract}

Background: Since 2019, the government of Zimbabwe has been making fiscal transfers to local governments as part of fulfilling the constitutional provisions to improve the socio-economic wellbeing of communities. Despite these transfers, there is limited research that establishes whether the funds are achieving the intended results.

Objective: The main focus of this paper was to assess progress towards the enhancement of the socio-economic rights of communities in the Mashonaland Central province of Zimbabwe through fiscal decentralization.

Method: This paper adopted qualitative methodology and the case study as the design. The Mashonaland Central province was purposively selected as it is one of the regions lagging behind in terms of development. Data was collected through, documentary analysis and key informant interviews with ten councilors, one Town clerk, nine Chief Executive Officers as well as ten focus group discussions with community members.

Findings: The study noted that since the transfer of funds to local authorities started in 2019, significant progress has been achieved in the fulfillment of socioeconomic rights. However, local governments were facing challenges such as the unavailability of an administrative manual to guide them in the implementation of fiscal decentralization, lack of clear funds allocation criteria, untimely and unpredictable distribution of funds, price instability, cumbersome procurement processes and lack of a monitoring and evaluation framework. These challenges were negatively affecting the attainment of the desired goals.

Conclusions and Recommendations: Fiscal devolution has already started paying dividends in enhancing the socio-economic rights of communities in the Mashonaland Central Province of Zimbabwe in key sectors such as water and sanitation, education, healthcare, infrastructure development, governance and administration, and peace and security. There is a need to develop an administrative manual for implementing fiscal devolution, timely disbursement devolution funds, use of virtual meetings in the wake of the Covid- 19 pandemic, integration of monitoring and evaluation mechanisms, and capacity building of local government policymakers and administrators.

Paper Types: Research Paper

Key Words: Fiscal Decentralization; Devolution; Socio-Economic Rights; Local Governments.

JEL Classification: $\mathrm{H} 3$ 


\section{Introduction}

Zimbabwe's 2013 Constitution recognizes three tiers of government - national, provincial and metropolitan councils and local authorities. This recognition marked a departure from the previous Lancaster House Constitution, in that, for the first time provincial and metropolitan councils and local authorities were formally recognized as levels of government. The Constitution has an expansive chapter on devolution, which some commentators say embraces the pathway of a developmental local governance system that has the potential to translate into inclusivity and equality in decision making (Wekwete, 2016). To this end, Moyo (2019) concurs with this narrative when he retorted that the constitutionalization of socio-economic rights has the potential of contributing to poverty alleviation and improved access to social goods through effective public participation of communities.

Before 2013, the Zimbabwean local government system was solely a creature of the statute (Mapuva, 2015). However, in 2013 a milestone was achieved with the constitutionalisation of the local government system in Zimbabwe. There are 92 local authorities in Zimbabwe with 32 being urban councils whilst 60 are rural district councils. These institutions are responsible for the provision of services that have a direct impact on the socio-economic well-being of the communities in their areas of jurisdiction. Some of the services include health services, solid waste management, education services, water and sanitation services, and roads and transport services (Mushamba, 2010).

In Zimbabwe, fiscal decentralization is not a new phenomenon as it dates back to the overall decentralization policy thrust adopted by the government after the attainment of independence in the early 1980s. The main objective of the decentralization policy was to address historical inequalities between the black majority and the colonial white minority populace. According to Chatiza (2010), these early reforms were adequately supported by loans and grants known as the Public Sector Investment Program (PSIP). During the first decade, significant progress was registered in areas like education and health. However, the adoption of the Economic Structural Adjustment Program (ESAP) in the early 1990s was followed by the subsequent rapid decline of the Zimbabwean economy in the late 1990s, resulting in the drying up of financial support to local governments. The immediate and gradual effect of the decline in fiscal support was the deterioration of services like road infrastructure, water, education and sanitation services. This also extended to the decline of good governance practice by local authorities due to a lack of capacity to effectively engage citizens in local decision-making processes. However, the adoption of the 2013 Constitution raised hopes for increased financial support to local governments because of the constitutional provision which states that at least $5 \%$ of the national budget must be given to sub-national governments. However, since 2013 this failed to materialize due to the reluctance of the central government to comply with the constitutional provisions until 2017 when there was a change of government.

In 2020 alone it was reported that the national government disbursed over \$1 billion Zimbabwe dollars in inter-governmental transfers (IGFT) towards community development projects such as basic social infrastructure for local communities (Matabvu, 2020). For the 2021 financial year, a budget of 19.5 billion Zimbabwean dollars was allocated to fiscal decentralization. The caveat to the allocations was that local governments must utilize the funds for socio-economic development.

According to its two-stage economic development blueprint, National Development Strategy I \& II (NDS I \& II) the Government of Zimbabwe aims to achieve an upper-middle-income economy by 2030. In line with this national vision, fiscal decentralization is an ideal vehicle for propelling Zimbabwe's developmental thrust in a manner that puts local governance at the center of the national agenda. However, the attainment of the government's target of an upper-middle-income economy status by 2030 can only be realized if socio-economic rights are fulfilled because they are considered as a precondition for good governance and democracy (Moyo, 2019). The promotion of socio-economic rights resonates well with several Sustainable Development Goals (SDGs), namely, SDG (3) on Good 
health and Well-being, SDG (4) on Quality Education and SDG (6) on Clean Water and Sanitation.

However, despite the availing of devolution funds since 2019 , there is a paucity of literature highlighting the impact of the funds transfers on the realization of the socio-economic rights of communities. This paper, therefore, sought to assess the impact of the transfers on the realization of the socio-economic rights of the communities where these funds were utilized. Further, the results of the study can become a source of relevant information that can be used by the Government to review the financial resource allocations process to enable the remodeling of relevant policies which should address the realities on the ground. It was, therefore, pertinent that an investigation be undertaken to establish if the utilization of IGFT funds by local governments was achieving the intended purpose.

The remaining part of this study is organized as Section III critically examines related literature; Section III outlines research methods. Section IV covers findings and Section V concludes the study.

\section{Review of Literature}

\section{Theoretical framework}

This study is underpinned by institutional theory which can be traced to the works of Selznick in the late 1950s. According to Berthod (2016), the institutional theory provides the lens to understand how organizations are designed and why they take certain positions when it comes to decision-making. Institutions are influenced by their internal and external environment with governments being one of the external environments that influences them through the enactment of policies and legislation to achieve desired outcomes. For public organizations like local governments, Thoening (2011)states that public organizations prefer not to be innovative but conform with government directives because such acts reinforce their political legitimacy and improve the social image of their members. Therefore, governments define the rules of the game and the actors who have to participate in the game, the agenda to be achieved and the punishment to be given in the event of any deviation. As a result of the above, organizations seek to become legitimate and become accepted by society through abiding by the rules and regulations set by governments.

The adoption and disbursement of inter-governmental funds to local governments in 2019 by the Government of Zimbabwe in conformity with constitutional provisions specifically section 301 (3). Through formal structures, local governments became recipients of the funds and have the obligation to implement projects as specified by the central government. Therefore, concerning this study, the institutional theory was used as a lens to establish the extent to which local governments have been influenced by institutional structures, laws and policies in implementing projects under fiscal decentralization in the pursuit of socio-economic rights in the Mashonaland Central province of Zimbabwe.

\section{Conceptual Review}

Devolution is generally considered a vehicle for socio-economic development (Conyers, 2003; Mnyasenga \& Mushi, 2015; Nhede, 2013; Chigwata, 2019; Zinyama \& Chimanikire, 2019; Vambe, 2019; Chikwawawa, 2019; ZEPARU, 2019; ZEPARU, 2020). Local economic development and poverty reduction are the major objectives of decentralization in Zimbabwe, as decentralization is regarded as a means of promoting rural development, principally through service delivery enhancement (Conyers, 2003). Expounding on this notion, Nhede (2013) asserts that that devolution engenders local development and national unity through fostering the acceptance of diversity, pointing out that devolution promotes local decision-making on infrastructural and economic development agendas in a manner that allows local authorities to initiate development plans appropriate to their regions, taking into consideration their distinctive challenges, priorities and opportunities. 
Likewise, Mnyasenga and Mushi (2015) opine that administrative decentralization of social and economic development, as an antidote to the deficiencies of a centralized system, and is a crucial condition for social and economic development as well as efficient and effective service delivery. Along the same vein, Muchadenyika (2015) posits that devolution of power and authority to local entities is crucial in enhancing the people's participation in the formulation and implementation of development initiatives and the development process in general. Similarly, Chikwawawa (2019) aptly asserts that the objectives of devolution in Zimbabwe is the realization of good and effective local government that affords citizens and communities economic and political power, through equitable sharing of national and local economic resources, as well as participation in decision-making on matters affecting their well-being. Furthermore, Chikwawawa (2019) opines that the sharing of political, administrative and fiscal powers empowers local authorities and local communities politically and economically, which is one of the ultimate goals of good governance.

Lack of political will has been identified as the major impediment to devolution (Jonga, 2014; Wekwete, 2016; Chikwawawa, 2019; Nyikadzino and Shikha (2020). In this regard, Jonga (2014) asserts that Zimbabwe has a very clear decentralization policy targeted at empowering local authorities and local communities, but owing to resistance and lack of political will, among other factors, it has not been possible to make meaningful progress in implementing the policy. Relatedly, Wekwete (2016) observes that the biggest challenge is the lack of the requisite political will needed to develop the necessary legislation to make the decentralization work. In concurrence with this view, Vambe (2019) asserts that political unwillingness to implement devolution has led to the delay in the development of the appropriate legal framework and has also led to the neglect of the alignment of the already existing legal framework, which is critical for the successful implementation of devolution.

Since the adoption of Constitutional Amendment, No 20 of 2013, several research studies have been carried out focusing on devolution, and the majority of them by scholars (Mapuva, 2015; Muchadenyika, 2015; Nyati and Ncube, 2017) focused on unpacking political decentralization and administrative structures leaving out fiscal decentralization. Therefore, this research covers this lacuna by evaluating the impact of fiscal decentralization on the attainment of socio-economic rights as a strategy to empower communities. This study offers a practical solution by interrogating the extent to which the utilization of the IGFT funds is contributing towards the fulfillment of socio-economic rights. Since fiscal transfer is still in its infancy, the results of this study could help the government to take early corrective measures before the adoption of the second National Development Strategy (NDS II 2026-2030). Further, the focus on local authorities could help to expose the institutional and policy gaps which can result in the crafting of appropriate capacity enhancement strategies.

\section{Conceptual framework}

Fiscal decentralization is one of the dimensions of decentralization. Boschmann (2009) defines decentralization as a gradual process that operates within a known legal framework and its components include administrative decentralization, political decentralization and fiscal decentralization. He further states that fiscal decentralization is the devolution of taxing and spending powers from the control of the central government to subnational tiers of governments. Economic Co-operation and Development (2006) defines it as the share of national governments expenditure with sub-national governments expenditure. The operationalization and success of fiscal decentralization depend on its interaction with institutions like local governments. Fiscal decentralization is used to achieve various purposes which include, improvement of service delivery, promotion of accountability, and good governance and is regarded as an equalization mechanism that promotes fairness and equity between regions or provinces (World Bank, 2007).

According to Ma (1997), intergovernmental funds transfer is broadly classified into two categories conditional and unconditional grants. In terms of a conditional grant, the central government transfers 
the funds to recipients and also spells out the purpose for which the funds must be used. There are variants to the conditional grants, first, there is the matching grant under which the government states that if it, for instance, spends USD100 then the local government must match with the same amount. Second, there are the matching-ended grants whereby the central government will put a ceiling to the maximum amount it will provide. Finally, there is the non-matching grant under which the local government is not required to provide any funds but must spend the funds allocated by the central government on the specific purpose as directed. The unconditional grants are provided by the central government to recipients as a lump sum without any conditionalities being attached to it.

In the Zimbabwean context, the central government guided the utilization of the intergovernmental funds through Circular Number 1 of 2019. The Circular states that the intergovernmental funds are meant for capital developmental projects in the following sectors, health, education, roads, electricity, water as well as plant and equipment. From the contents of the Circular highlighted above, it is clear that fiscal decentralization in Zimbabwe falls within the ambit of a conditional grant under the nonmatching grant dimension because it meets the conditions noted by Boschmann (2009) which include the availability of a legal framework under section 301 (3) of the Constitution. Further, the grant gives specific areas of interest to the central government, whilst giving local government limited latitude to choose the specific projects to undertake within the defined parameters. It can also be noted that the areas specified by the central government resonate with Declaration of Rights of the Constitution, especially sections $73,75,76$ and 77 on socio-economic rights.

\section{Research methods}

\section{Study Area}

Figure 1: Map of Mashonaland Central Province

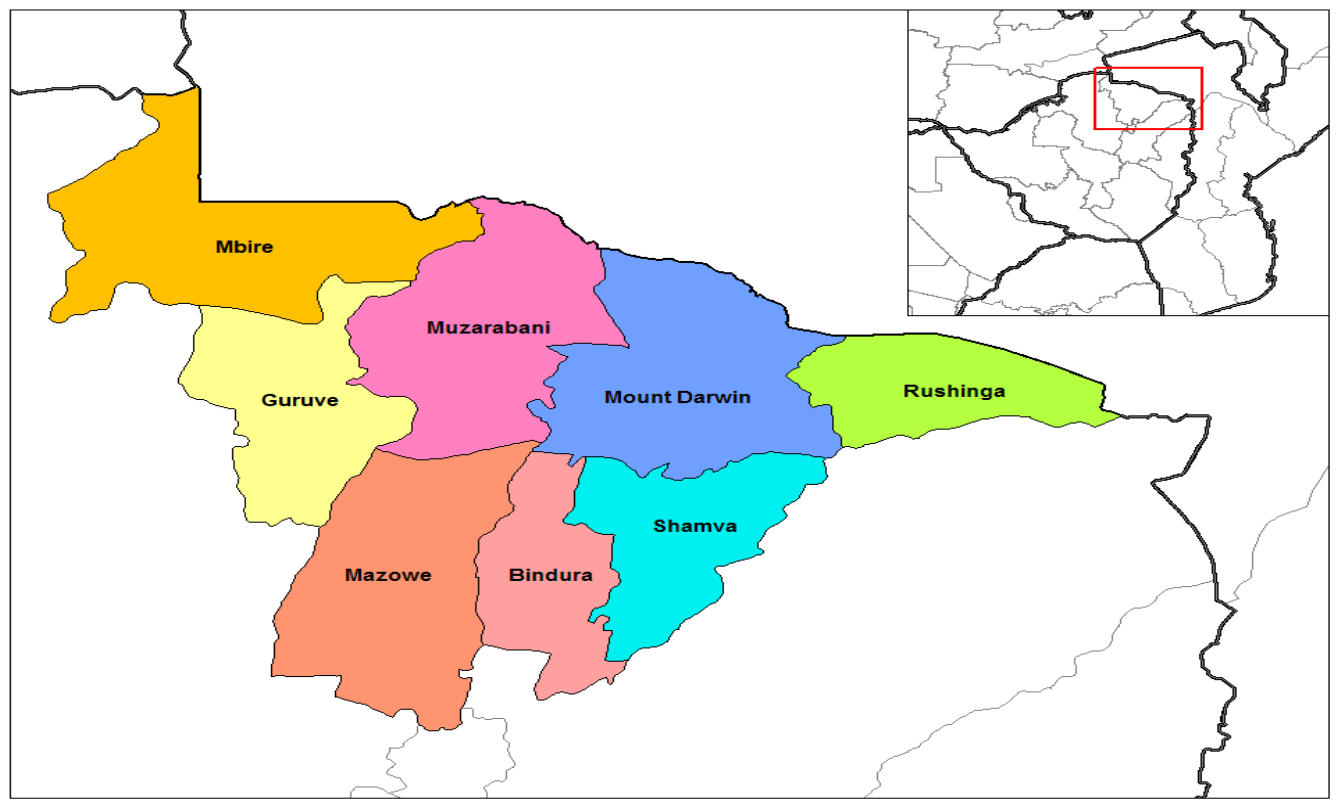

Mashonaland Central province is one of the ten administrative provinces in Zimbabwe. The province covers 28, 347 square kilometers and is located in the northeastern part of the country bordering Zambia to the north and Mozambique to the east. There are 10 local authorities in the province, two 
being urban councils and eight being Rural District Councils (RDC). In terms of infrastructure such as roads, telecommunication, electricity, water provision, schools and clinics, urban areas have better infrastructure as compared to the rural areas. However, due to years of inadequate funding and neglect, most of the infrastructure in the province is in a dilapidated state and some require rehabilitation and upgrading whilst in other situations require the construction of new ones (Ministry of Local Government and Public Works, 2013).

In terms of population distribution, $92 \%$ of the inhabitants in the province reside in rural areas, that is in farms and communal areas. A total of $8 \%$ reside in urban settlements which comprise a municipality, a town, and some growth points located in the various districts of the province. Mashonaland Central province is the least developed province in Zimbabwe.

\section{Data Analysis}

This qualitative research was informed by the interpretivism philosophy. The case study research design was adopted because of its effectiveness in carrying out an in-depth interrogation of a contemporary phenomenon within its real-life context (Yin, 2009). From the 10 provinces of Zimbabwe, Mashonaland Central province was purposively selected to be the area of study because it is one of the least industrialized and urbanized provinces in the country. As such, it provides the ideal context to establish the impact of an intervention like fiscal decentralization, particularly on the realization of socio-economic rights. Data collection was done through key informant interviews with 10 elected policymakers who included one mayor and nine chairpersons of rural district councils. From the administration side of the councils, key informant interviews were held with one town clerk, one town secretary, and eight chief executive officers. To capture the views of the beneficiaries of fiscal devolution, 10 focus group discussions with community members were held in compliance with Covid-19 health guidelines. The data was augmented by secondary data accessed from documents such as the Constitution of Zimbabwe Amendment Act (No.20) Act of 2013, policy documents like Vision 2030 which is the economic development blueprint for Zimbabwe, periodic progress reports by the local authorities, and online publications.

Purposive sampling was adopted in selecting the 10 senior employees of councils because of their positions and knowledge of the area under study. The same sampling method was also used in collecting data from the council chairpersons and mayor as they are the senior policymakers in councils. The community members were randomly selected in each district and grouped according to age and sex. Data gathered from the key informants and focused group discussions were analyzed using thematic analysis as it helped in identifying patterns and themes.

\section{Duration of the Study}

The study was undertaken over seven months from January 2021 to July 2021. Data collection was prolonged because of the restrictions imposed by the Government in response to the outbreak of Covid-19. These restrictions curtailed easy access to some data from Government agencies and hindered physical interviewing of respondents.

\section{Data Analysis and Results}

Since the commencement of the intergovernmental transfers in 2019, significant progress towards the enhancement of socio-economic rights was made by local authorities in Mashonaland central province. In terms of the release of funds to local governments, the central government has been fulfilling its promise to comply with provisions of section 301 (3) of the Constitution, which compels it to allocate at least five percent of the national revenue to lower tiers of government. From 2019 to 2020, Mashonaland Central province received a total of 91,812,764.00 Zimbabwean dollars, which was distributed to the ten local authorities as follows: 
Figure 2: Funds distributed to local authorities in Mashonaland Central province.

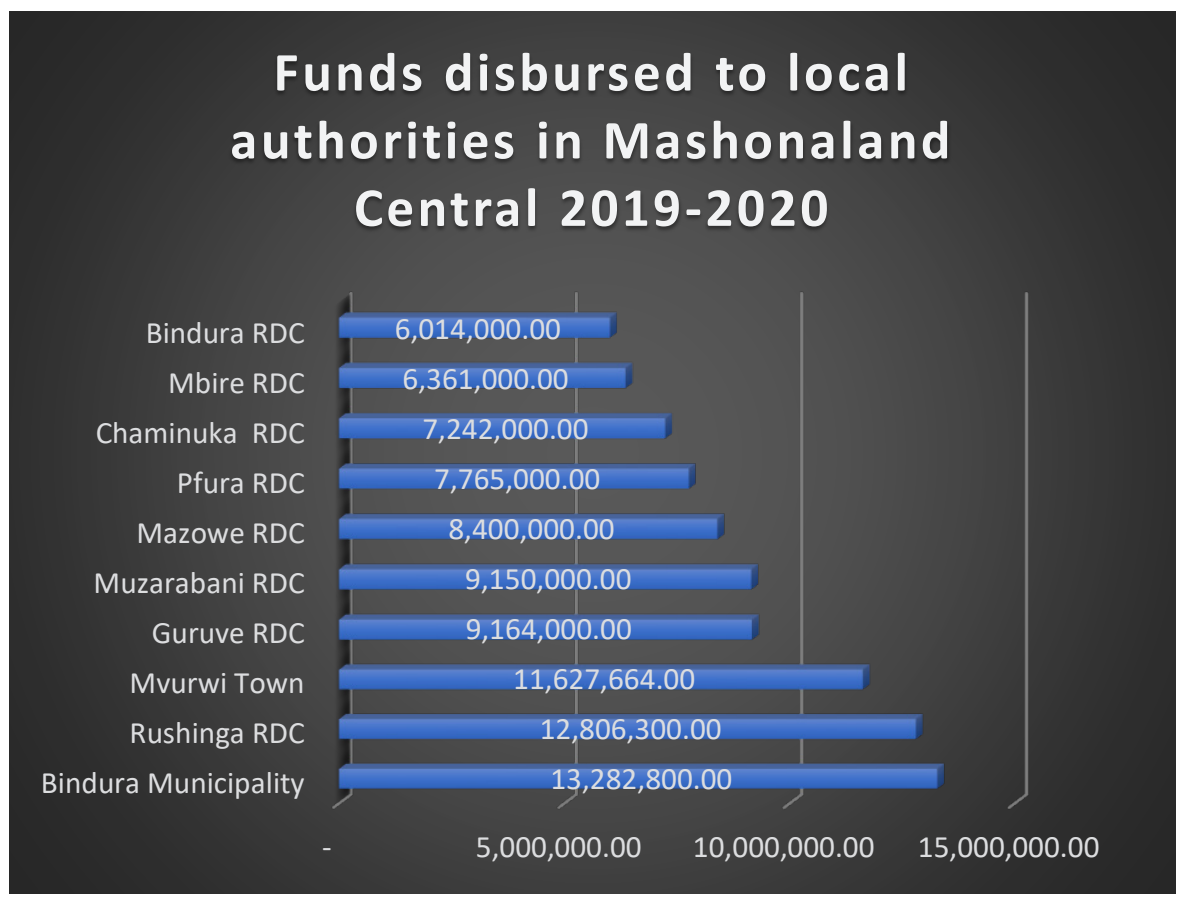

Source: Ministry of Local Government and Public Works, Mashonaland Central Province Report.

As shown in Figure 2, Bindura Municipality, which is the capital of the province received the highest amount of 13,282,800.00 Zimbabwean dollars translating it to $14.47 \%$, whilst from the rural district councils, Rushinga RDC received the highest amount of 12,806,300.00 Zimbabwean dollars, translating it to $13.95 \%$. Overall, Bindura RDC received the least amount of 6,014,000.00 Zimbabwean dollars translating it to $6.55 \%$. However, despite the disparities in the funds received, all local authorities managed to register significant progress on projects and this has a positive impact on the socioeconomic well-being of communities as detailed below:

\section{Major Achievements by Local Authorities}

The ten local authorities prioritized different projects which can be broadly classified under the following strategic pillars:

\section{Water and Sanitation}

From the progress reports submitted to the Ministry of Local Government and Public Works, Chaminuka RDC managed to drill five boreholes in five wards to improve access to safe, clean and potable water. Bindura Municipality carried out major water plant rehabilitation works as well as water and sewer network rehabilitation. Whilst Bindura RDC managed to drill two boreholes one for rural schools and the rest for community members. Pfura RDC constructed public toilets at its main bus terminus in Mt Darwin. Mvurwi Town focused on sewer stabilization ponds and drilling of two boreholes. The implementation of all the above projects resonates well with the provisions of section 77 of the Constitution of Zimbabwe which reads, "Every person has the right to safe, clean, and potable water". Further, the implementation of these projects is in tandem with aspirations of Sustainable Development Goals (SDGs), especially SDG 6, which calls for the universal achievement of clean water and sanitation. 


\section{Education}

It was highlighted in the key informant interviews with the elected officials and the chief executive officers that Rushinga RDC managed to construct four classroom blocks and two teacher's houses. Bindura Municipality constructed a new school called Brockdale Primary School. Mbire RDC prioritized the electrification of its schools. In Guruve the local authority constructed a science laboratory at Chifamba High school, whist Pfura RDC carried out renovations at four classroom blocks. The dutybearers highlighted that they prioritized the education sector in line with the provisions of section 75 of the constitution, which compels them to provide access to education for children in their areas of jurisdiction. Further, the officials stated that they prioritized the education sector because their districts were lagging behind other provinces in terms of appropriate infrastructure due to the effects of the war of independence experienced in the 1970s.

\section{Health}

The focused group discussions held with respondents indicated that access to health was a major challenge, especially in rural areas. The participants stated that in most communities people traveled over 20 kilometers to access health services and this was negatively affecting the right to healthcare as required by section 76 of the Constitution. As a result, Chaminuka RDC channeled its financial resources towards the construction of a clinic to improve access to health by its communities. On the same note, Rushinga RDC managed to construct two clinics namely, Nyatsato and Chomutukutu. This was also complemented by the construction of houses for health personnel at these clinics. These clinics were serving a combined population of about nine thousand people. In response to the outbreak of the Covid-19, Bindura RDC managed to renovate a structure that became the provincial Covid-19 isolation center. Muzarabani RDC constructed three clinics and all were near completion by the time of this study. Therefore, the projects prioritized by the local authorities contributed to the realization of the right to health care as enshrined in Section 76 of the Constitution. This finding, thus, confirms what was established in the reviewed existing literature (Conyers, 2003; Nhede, 2013; Chigwata, 2019; Vambe, 2019; ZEPARU, 2020). Vambe (2019), for instance, points out that devolution contributes to the improvement of service delivery and socio-economic development in local communities. Likewise, concerning the provision of healthcare, ZEPARU (2020), posits that potential benefits of fiscal devolution include the provision of effective health and educational systems and services at local levels.

\section{Plant and Equipment}

Chaminuka RDC purchased a refuse compactor to manage the disposal of solid waste. Rushinga RDC purchased a tipper truck and a motorbike. Guruve RDC purchased a backhoe loader and a motor vehicle for projects monitoring. Muzarabani RDC procured a vehicle for project monitoring, while Mvurwi Town purchased a water bowser to mitigate erratic water supplies. Respondents stated that recapitalization of the local authorities was key to the provision of services such as road maintenance. This dovetailed with what was highlighted in the reviewed literature for this study. For example, ZEPARU (2020) underscored the importance of the timely provision of finances as one of the critical success factors for devolution.

\section{Animal Healthcare}

Mbire RDC constructed two dip tanks and a slaughterhouse for cattle. According to respondents from the district, they prioritized animal healthcare because their area is predominantly a wildlife district so their livestock especially cattle were highly exposed to the foot and mouth disease which is spread by buffaloes. Therefore, they wanted their cattle to be healthy as they use them for a variety of purposes which include, draught power, provision of manure for gardening as well as provision of milk and 
meat. The use of devolution to address the community's relevant socio-economic needs attests to the contribution of fiscal decentralization to the enjoyment of socio-economic rights as underscored in literature (Conyers, 2003; Mnyasenga and Mushi, 2015; Nhede, 2013; Vambe, 2019; ZEPARU, 2019; ZEPARU, 2020).

\section{Governance and Administration}

Rushinga and Pfura RDC managed to electrify their offices by way of a solar system whilst Muzarabani installed a solar system and information and communication technology (ICT) infrastructure at its offices. The councillors, who were interviewed, stated that these solar systems were going to improve service delivery because their districts used to experience serious electricity blackouts which affected the normal operations of the council. This finding clearly shows the contribution of fiscal devolution to socio development, thereby, contributing to the enjoyment of socio-economic rights by local communities as envisaged in some of the reviewed existing literature (Conyers, 2003; Mnyasenga \& Mushi, 2015).

\section{Infrastructure and Local Economic Development}

Bindura Municipality and Guruve RDC constructed bridges to facilitate access from one community to another in areas separated by rivers and other water bodies. Pfura RDC rehabilitated its public transport passengers' shades at its main bus terminus. Manifestly, this finding shows the crucial contribution of fiscal devolution towards the realization of socio-economic rights by local communities, as their economic and social welfare was clearly enhanced. In terms of local economic development, Bindura Municipality constructed the Chipadze Flea Market to support income generation projects of residents. In the focused group discussion held in Bindura, respondents stated that the flea markets were going to improve their livelihoods since the informal sector was currently the backbone of the Zimbabwean economy clearly attesting to the contribution of fiscal devolution to socioeconomic development.

\section{Peace and Security}

Rushinga RDC managed to construct a Police Post to ensure the availability of law enforcement agents for its marginalized communities in the Mukosa area especially to young vulnerable girls who were being forced into early marriages while Muzarabani RDC installed solar street lights to curb criminal activities as these are usually perpetrated in dark environments. In these regards, the findings indicate the contribution of fiscal devolution to socio-economic development in the localities under study, thus confirming what was highlighted in some of the reviewed literature (Conyers, 2003; Mnyasenga and Mushi, 2015; Nhede, 2013; Vambe, 2019; Chikwawawa, 2019; ZEPARU, 2019; ZEPARU, 2020).

\section{Challenges}

\section{Unavailability of Administrative Manual}

Since the implementation of the IGFT in 2019, no administrative manual has been developed to guide local authorities. The non-availability of the manual has resulted in different interpretations on what qualifies to be purchased, especially concerning the procurement of vehicles. Some local authorities managed to purchase vehicles that they argued were meant for project monitoring whilst others had their requests turned down. This lack of the administrative manual was cited by some local authorities as a loophole that was being abused by some junior officers in the Ministry of Local Government and Public Works to direct the treasurers of councils to remove some budget items even though the council would have made a resolution passing the budget. Therefore, the lack of an administrative manual was affecting the implementation of projects since administrative officers lacked clear policy guidance. 


\section{Unclear Funds Allocation Criteria}

The criteria that were being used to allocate funds to councils were a cause of concern, with the urban councils, on one hand, arguing that they should get more funding since they have the highest number of dilapidated infrastructure which needed to be rehabilitated and upgraded. On the other hand, the rural district councils argued that they deserved more funding because, firstly the urban councils inherited better infrastructure after the attainment of independence in 1980, as they were given preferential treatment by the post-independence government in terms of resource allocations. Rural district councils also highlighted that all statistical indicators showed that rural areas were the least developed in terms of access to healthcare facilities, schools, clean, safe and potable water and road infrastructure so they deserved to receive more funding as compared to urban councils. There is, therefore, a need to put finality to the issue of how funds should be allocated to councils through an agreed allocation formula.

\section{Unpredictable Release of Funds}

Both urban and rural local authorities bemoaned the lack of a clear time frame for the release of funds to them by the Ministry of Finance and Economic Development. It was highlighted that in most circumstances funds were deposited in the bank accounts of local councils without any notification. Further, the disbursements were made around June instead of January. Therefore, this was affecting the council's work plans. The council officials indicated that they usually received large sums of funds towards the end of December when the financial year is almost closing such that there would not be enough time to implement planned projects. This lack of clarity on the timing of the release of funds caused some contractors to abandon projects due to erratic payments for work carried out and the unavailability of raw materials. Further, suppliers were no longer willing to supply goods and services to councils as they viewed them as unreliable in terms of payment for goods delivered or services rendered.

\section{Unstable Prices of Goods and Services}

Before August 2018, the Zimbabwean economy was using the United States Dollar as its trading currency. But due to liquidity challenges, the Reserve Bank of Zimbabwe introduced a local currency that initially traded at an equivalent exchange rate with the United States Dollar. However, this did not last long as the local currency started losing its value against the United States Dollar and as a result, a black-market rate emerged and traders started pegging their prices using the black-market rate to hedge against inflation. The traders also started rejecting the local currency preferring united states dollars for all goods in services. To address this anomaly, the government of Zimbabwe issued Statutory Instrument 85 of 2020 which directed the use of the Zimbabwean currency exclusively for all domestic transactions. However, the reality has been that the black market has been on the rise whilst the official rate has remained static as shown below:

To solve this challenge, the Central Bank of Zimbabwe then introduced a foreign currency auction system which was envisaged to be a mechanism to allocate foreign currency to companies. However, the scarcity of foreign currency from the official auction system has resulted in most traders sourcing it from the black market to procure their stocks. Given this, goods sold to local governments are priced using the black-market rate, not the official rate. Therefore, the effect has been the reduction in terms of quantities of goods purchased or cancellation of tenders because the purchasing power of the funds would have been eroded. This has negatively impacted the completion of projects which have the potential to enhance the socio-economic status of communities. 
Figure 3: Zimbabwe exchange rate movements

\section{Zimbabwe exchange rate movements:Official against Black Market 2019-2020}

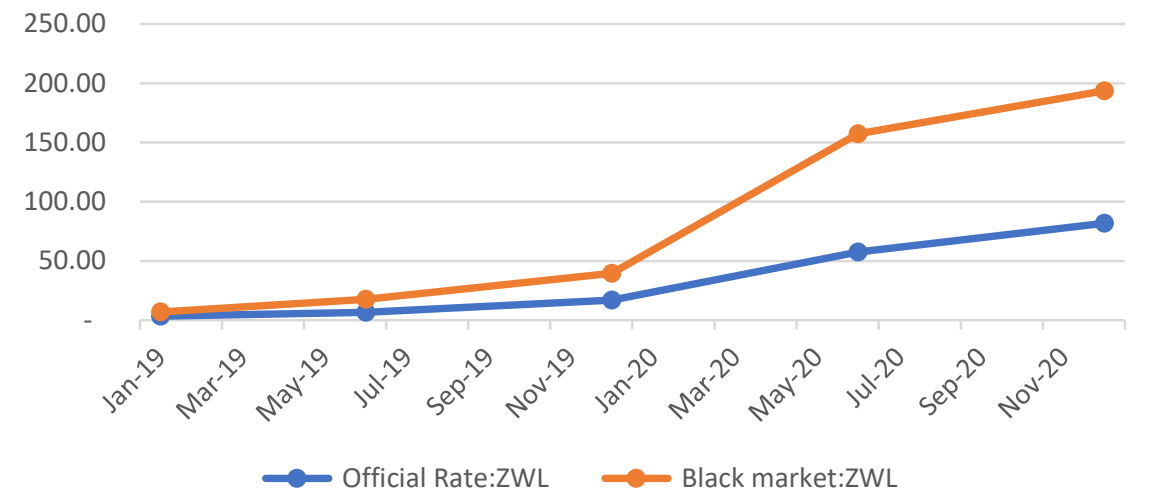

Source: Zimbabwe market watch

\section{Procurement Process}

Procurement processes by public institutions in Zimbabwe are regulated by the Public Procurement and Disposal of Public Assets Act [Chapter 22:23] and numerous guidelines and regulations which should be strictly complied with. It was noted that the procurement process was cumbersome and impeded the expeditious acquisition of goods and services in an inflationary environment, thereby resulting in reduced quantities of goods and services procured, which in turn, negatively affected the completion of projects.

\section{Lack of Monitoring and Evaluation Mechanism in Projects}

Monitoring and evaluation are key concepts that should be infused into the management of projects. Although monitoring and evaluation are viewed as related, they are distinct functions. On one hand, monitoring is viewed as a process that provides information and ensures the use of such information by management to assess project effects-both intentional and unintentional and their impact. It aims at determining whether or not the intended objectives have been met. Evaluation, on the other hand, draws on the data generated by the monitoring system as a way of analyzing the trends and impacts of the project (Burke,1999).

This study indicated that monitoring and evaluation of projects were not included in the project planning phase. The respondents highlighted that monitoring of projects was not being prioritized as it was viewed as a waste of funds and time-consuming. If such a monitoring and evaluation visit was done, it was indicated that it would be as a result of a tour by officials from the central government.

\section{The Outbreak of the Covid-19 Pandemic}

The outbreak of the Covid-19 pandemic had a serious negative impact on the operations of local authorities as they were ill-prepared to operate in an environment that imposed lockdowns and restrictions on meetings and gatherings. As institutions, local authorities in Mashonaland Central were supposed to comply with statutory instruments that were promulgated for the prevention and containment of Covid-19, especially on the convening of physical meetings. The failure to hold meetings and pass resolutions affected the implementation of projects, resulting in some of them being delayed or set aside. 


\section{Dependence Syndrome and Erosion of Good Local Governance Practice}

IGFT can be viewed as readily accessible funding which supports the fulfillment of the constitutional provision on devolution. Its availability has, however, created room for dependence syndrome among local authorities which have become reluctant to pursue other sources of revenue generation which they deem difficult to collect. Since local authorities are aware that all capital expenditure is covered by IGFT, they end up pursuing limited sources of revenue to meet their administrative costs, especially salaries.

\section{Conclusions and recommendations}

This paper established that fiscal devolution has already started paying dividends in enhancing the socioeconomic rights of communities in the Mashonaland Central Province of Zimbabwe. Significant strides have been realized in key sectors, such as water and sanitation, education, healthcare, infrastructure development, small-to-medium enterprises development, governance and administration, and peace and security. Progressive realization of these socio-economic rights is a step in the right direction towards the attainment of Zimbabwe's Vision 2030, the National Development Strategy I \& II (NDS1\&II), the African Union Agenda 2063 and the United Nations Sustainable Development Goals.

Notwithstanding the positive inroads that fiscal decentralization has made so far in terms of fostering the enjoyment of socio-economic rights by local communities, it is currently lumbered with a plethora of challenges militating against its effective and efficient implementation. The challenges include the unavailability of an administrative manual to guide local authorities in the implementation of fiscal decentralization, lack of clear funds allocation criteria, untimely and unpredictable distribution of funds, price instability owing mainly to inconsistencies in monetary policies, cumbersome procurement processes and lack of a monitoring and evaluation framework for projects financed through fiscal devolution. These challenges have been severely compounded by the Covid- 19 pandemic which has led the government to interminably institute measures such as lockdowns and restrictions of meetings and gatherings, with profound adversative implications for the implementation of projects financed through fiscal devolution.

Despite these challenges, fiscal decentralization is undoubtedly an effective vehicle for economic development. For effective implementation of fiscal decentralization to be attained, there is a need for government to develop an administrative manual to guide local authorities in implementing fiscal devolution. There is also a need to timeously disburse devolution funds to local authorities to ensure that the implementation of projects is not unnecessarily delayed. In the wake of the pervasive and seismic Covid- 19 pandemic and the resultant lockdown measures it gives rise to, such as the restriction of physical meetings, local authorities are advised to consider making use of virtual meetings, whenever possible, to ensure that projects are not stalled by their inability to hold physical meetings. In addition, integration of monitoring and evaluation mechanisms in the projects for constant checking of progress and impacts is required. Capacity building of local government policymakers and administrators on principles of good governance and democracy to ensure community participation, as well as transparency and accountability in project implementation and management, is also a compelling requirement. That said, it can be concluded that there are high prospects of success for enhancing the realization of socio-economic rights by communities in Mashonaland Central Province of Zimbabwe, through fiscal decentralization.

\section{Conflict of Interest}

Author(s) declare no conflict of interest while preparing this article. 


\section{References}

Berthod, O. (2016). Institutional theory of organizations. Global encyclopedia of public administration, public policy, and governance, 1-5.

Boschmann, N. (2009). Fiscal decentralization and options for donor harmonization. Berlin:

Development Partners Working Group on Local Governance and Decentralization DPWG-LGD.

Chatiza, K. (2010). Can local government steer socio-economic transformation in Zimbabwe? Analyzing historical trends and gazing into the future. Western Cape: Local Government Working Paper Series No.1. Community Law Centre.Constitution of Zimbabwe Amendment (No. 20) Act 2013.

Chigwata, T.C. (2019). Decentralization and constitutionalism in Zimbabwe: Can the Leviathan be tamed?' in Fombad C and Steytler N (eds) Decentralization and Constitutionalism in Africa. Oxford: Oxford University Press.

Chikwawawa, C. (2019). Constitutionalisation and implementation of devolution in Zimbabwe. International Journal of Scientific and Research Publications, 9(3), 19-25.

Conyers, D. (2003). Decentralization in Zimbabwe: A local perspective. Public Administration and Government of Zimbabwe. (2018). Vision 2030. Harare: Government Printers.

Government of Zimbabwe. (2020). Statutory instrument 85 of 2020. Exchange control (Exclusive use of Zimbabwe dollar for domestic transactions) (Amendment) regulations. Harare: Government Printers.

Jonga, W. (2014). Local government system in Zimbabwe and associated challenges: Synthesis and antithesis. Archives of Business Research, 2(1), 75-98.

Ma, J. (1997). Intergovernmental fiscal transfers in nine countries: Lessons for developing countries. Washington, DC: World Bank.

Mapuva, J. (2015). The controversies of devolution in Zimbabwe. International Journal of Political Science and Development, 183-192.

Matabvu, D. (2020). Devolution projects gets massive boost. The Sunday Mail. Accessed from https://www. sundaymail.co.zw/1-billion-for-devolution-projects

Moyo, K. (2019). Socio-Economic rights under the 2013 Zimbabwean Constitution. In Raoul. Wallenberg Institute, Selected aspects of the Zimbabwean Constitution and the declaration of rights (pp. 163-181). Lund: Raoul Wallenberg Institute.

Ministry of Local Government, Public Works and National Housing. Local Authorities

Circular No. 1 of 2019. Guidance on the utilization of devolution funds.

Mnyasenga, T.R. and Mushi, E.G. (2015). Administrative Legal framework of central-local government relationship in Mainland Tanzania: Is it tailored to enhance administrative devolution and local autonomy? International Review of Management and Business Research, 4 (3), pp. 931-944.

Mushamba, S. (2010). An analysis of powers and functions of local government authorities in Zimbabwe. Western Cape: Local Government Working Paper Series No. 5.Community Law Centre.

Muchadenyika, D. (2015). The inevitable: Devolution in Zimbabwe - from constitution-making to the future. In de Visser, J.,Steytler, N., Powell, D. And Durojaye, E. (Eds) Constitution-Building In Africa. Community Law Centre, University of the Western Cape.

Munyede, P. and Ndlovu, Z. (2019). Giving traction to human rights in local governance: Human rights manual for local governance practitioners. Association of Rural District Councils of Zimbabwe. 2019 Human Resources Winter School 17-20 September (1-12). Rainbow Hotel Bulawayo.

Nhede, N. T. (2013). Devolution of power and effective governance: The Zimbabwean constitutional debate African Journal of Public Affairs, 6(4), 32-42.

Nyikadzino, T. and Shikha V. (2020). The devolution of governmental powers and responsibilities in postindependent Zimbabwe. African Renaissance, 17(1), 233.

Organisation of Economic Coorperation and Development. (2006). Intergovernmental transfers and decentralised public spending. OECD Journal on Budgeting. The International Covenant on Economic, Social and Economic Rights. Accessed from: https://treaties.un.org/1976/01 
Thoening, J.C. (2011). Institutional theories and public institutions: New agendas and appropriateness. In B. P. Pierre., The handbook of public administration (pp. 1-17). London: Sage.

United Nations. (2015). Transforming our world: The 2030 agenda for sustainable development. United Nations.

Vambe, G.R. (2019). realization of socio-economic rights through devolution in Africa: The case of Kenya and Zimbabwe. A dissertation submitted to Midlands State University in partial fulfillment of the requirements of the Master of Laws (LLM) Constitutional and Human Rights Law.

Wekwete, K. H. (2016). Constitutionalism and local government in Zimbabwe. In strengthening capacity for local governance and service delivery in Zimbabwe Project The Constitution of Zimbabwe 2013 as a basis for local government transformation: A reflective analysis. Commonwealth Local Government Forum Southern Africa Regional Program.

Yemek, E. (2005). Understanding fiscal decentralization in South Africa, IDASA-Budget Information Service Accessed from: http://www.idasa.org,za

World Bank. (2007). Intergovernmental fiscal transfers: Principles and practice. Washington D.C: World Bank .

Yin, R. K. (2009). Case study research: Design and methods. California: SAGE Publications, Inc.

ZEPARU. (2019). Exploring key success factors in implementing devolution in Zimbabwe. Harare: Zimbabwe Policy Analysis and Research Unit (ZEPARU).

ZEPARU. (2020). Policy brief: Towards successful implementation of devolution in Zimbabwe: Harare: Zimbabwe Policy Analysis and Research Unit (ZEPARU).

Zimbabwe Market Watch. Retrieved from https://www.marketwatch.co.zw/2021/07/

Zinyama, T., and Chimanikire, D. (2019). The nuts and bolts of devolution in Zimbabwe: Designing the provincial and metropolitan councils. African Journal of Public Affairs, 11(2), 147-176. 